merce and Labor and by the Bureau of Fisheries of that department has been in accordance with the law; that the regulations issued from time to time by the department and the instructions issued to the agents have been properly observed; that the fur-seal herd has been handled intelligently; and that the charges have not been sustained.

The charges of 'malfeasance brought with such a flourish against the Department of Commerce and Labor by Mr. Henry W. Elliott, with the support of Dr. William T. Hornaday and a very small minority of the Camp Fire Club, whom the majority report characterizes as "public spirited citizens," have proved a fiasco. It is said that they influenced the action of congress in suspending land sealing. We can well believe this. The aforesaid congressional action provides for the throwing away of $\$ 2,500,000$ worth of sealskins, jeopardizes the permanence of a beneficent treaty which is essential to the only salvation of the herd, and inflicts upon the rookeries a horde of idle fighting bulls to work destruction among the breeding females and their young. There is a close resemblance between this ill-advised action of congress and the equally unwarranted investigation, as disclosed in the dual report of the committee conducting it.

If congress had wished to enact a law for the encouragement of pelagic sealing it could scarcely have done so more effectively than it did when it prohibited commercial killing on the land of the surplus male seals.

$$
\begin{aligned}
& \text { George Archibald Clark } \\
& \text { Stanford Universitr, CaL., } \\
& \text { February 11, } 1913
\end{aligned}
$$

\section{THE ALPINE LABORATORY}

The Alpine Laboratory is situated at 8,500 feet on the Cog Railway between Manitou and the summit of Pikes Peak. The flora is both rich and varied, and in connection with the remarkable diversity of habitat found in this rugged mountain region offers exceptional opportunities for the study of plant response, and the origin of new forms. Among the alpine summits of the continent, Pikes Peak is unique in the series of great formational zones which lies across its face. From the Great Plains grasslands, the series runs from valley woodland at 5,800 feet to mesa, chapar ral, foothill woodland, pine forest, aspen woodland and spruce forest to alpine meadow, rock field and bog at 11,000-14,000 feet in a distance of 7 miles. From the very nature of the mountains, weathering, erosion and other physiographic factors bring about the almost countless repetition of the same or similar habitats, and produce numbers of primary and secondary successions illustrating a wide range of developmental processes and principles.

Ecological work was first done at Pikes Peak in 1899, and has been carried on each summer since that time. In consequence, it is probable that no other area has been so intensively studied by means of instrument and quadrat, and offers such a fascinating array of ecological problems for which the foundation has at least been sketched. The scope and nature of this foundation work is indicated by the following publications: "Development and Structure of Vegetation, 1904"; "Research Methods in Ecology, 1905"; "Relation of Leaf Structure to Physical Factors, 1905 "; "Vegetation of the Mesa Region, 1906"; "Life History of the Lodgepole Burn Forests, 1909"; "Natural Vegetation as an Indicator, 1910"; "Wilting Coefficient, 1911," and "Development and Structure of Sandhill Vegetation, 1913."

The practical aspects of quantitative ecology are represented by the Fremont Forest Experiment Station, and the Dry-land Agriculture Field Station of the U. S. Department of Agriculture, perhaps the best equipped stations in the world for the exact study of vegetational problems.

The field of investigation open falls into four general divisions: (1) the use of quantitative methods of studying habitat and plant; (2) the application of ecological methods and principles to forestry, agriculture and plant pathology; (3) the measured study of individual response to the habitat with especial reference to the origin of species; (4) quadrat study of the development and structure of plant formations. The oppor- 
tunity for applying the exact methods of modern ecology to the problems of Silvics, Forest Pathology, Dry-land Agriculture, Plant Breeding and Experimental Evolution is unsurpassed. Opportunity will also be offered for the taxonomic study of the varied flora.

While the plan contemplates graduate work primarily, advanced students in botany or related subjects, such as forestry and agronomy, will be accepted, provided they have had sufficient training to enable them to work on individual problems under adequate supervision. It is hoped that the opportunity will be especially welcome to foresters, pathologists, agronomers and teachers of botany who have not yet become acquainted with the methods and outlook of exact ecology, and its many applications to practical plant science. The summer's work will be accepted as the full equivalent of a semester's work for the master's or the doctor's degree at the University of Minnesota, and the University of $\mathrm{Ne}$ braska. It is expected that other universities will permit similar arrangements.

The University of MinNesota

Frederick E. Clements

\section{SCIENTIFIC NOTES AND NEWS}

Dr. Felix KLEIN, professor of mathematics at Göttingen, is about to retire from active service.

Mrs. A. R. W ALLACE writes to an American correspondent: "Dr. Wallace is very well and busy, writing as hard as ever; he has just passed 90, and feels like 50."

Dr. JAMES M. TAYLOR will retire from the presidency of Vassar College at the close of the present year.

Dr. Alexis Carrel, of the Rockefeller Institute for Medical Research, has been appointed a knight of the Legion of Honor by the French government.

Dr. F. W. Putnam, professor emeritus of anthropology at Harvard University, has been elected non-resident vice-president of the Washington Academy of Sciences.

Professor S. W. Williston, of the University of Chicago, will attend the ninth Inter- national Congress of Zoology as the delegate at large of the American Zoological Society.

The Lalande Prize, of the Paris Academy, has been awarded to Professors H. Kobold and W. Wirtz for their work on the determination of the motions of nebulæ.

The Bessemer gold medal of the Iron and Steel Institute will be awarded to $\mathrm{Mr}$. Adolphe Greiner, general director of the Société Cockerill, Seraing, at the annual meeting to be held in London on May 1 and 2 .

$\mathrm{A} T$ the last meeting of the Royal Australasian Ornithologists' Union of Melbourne, Australia, Dr. R. W. Shufeldt, of Washington, D. C., was elected an honorary member.

Two bronze horses, made by George Ford Morris, the New York animal artist, illustrating the points of an ideal draft horse, and the deficiencies of an inferior horse, have been presented to Dr. A. S. Alexander, of the University of Wisconsin, in recognition of his work in developing the horse breeding industry, both of Wisconsin and the country at large.

Dr. Edward A. Burt, professor of natural history (botany) in Middlebury College, Middlebury, Vt., has been appointed librarian and mycologist of the Missouri Botanical Garden, St. Louis, Mo. He will leave Middlebury at the close of the present college year and begin his work at the Missouri Botanical Garden in September.

$\mathrm{A}_{\mathrm{T}}$ the recent annual meeting of the board of managers of the Wistar Institute of Anatomy and Biology, Dr. Helen Dean King was elected assistant professor of embryology. Dr. King will continue the embryological work of the institute which was begun two years ago by Professor G. Carl Huber, who has returned to the University of Michigan.

Dr. Robert H. Lowie, of the department of anthropology of the American Museum of Natural History, has been promoted to the rank of associate curator.

Mr. William Robert Ogilvie Grant has been promoted to be assistant keeper of the department of zoology at the Natural History 